\title{
ON-LINE TOOLS TO IMPROVE THE PRESENTATION SKILLS OF SCIENTIFIC RESULTS
}

\author{
M. Campos-Taberner ${ }^{1}$, M.A. Gilabert ${ }^{1}$, J.A. Manzanares ${ }^{1}$, S. Maféé, J. Cervera ${ }^{1}$, \\ F.J. García-Haro'1, B. Martínez', V. García-Morales', P. Ramírez², V.M. Aguilella ${ }^{3}$, \\ M.I. Aguilella ${ }^{3}$, A. Alcaraz ${ }^{3}$ \\ ${ }^{1}$ Departament de Física de la Terra i Termodinámica, Facultat de Física, Universitat de \\ València (SPAIN) \\ ${ }^{2}$ Departament de Física Aplicada, Universitat Politècnica de València (SPAIN) \\ ${ }^{3}$ Departament de Física, Universitat Jaume I de Castelló (SPAIN)
}

\begin{abstract}
Learning how to effectively communicate scientific results is essential for upper undergraduates and graduates. Our previous projects on this topic have identified the need to incorporate web questionnaires and other interactive content into the educational program, as they meet the students' demands and provide a training feedback. To facilitate the acquisition of communication skills, we are developing materials that combine information and communications technology (ICT) self-learning environments with traditional classroom teaching (blended learning).
\end{abstract}

Keywords: communication of scientific results, presentation skills, blended learning.

\section{INTRODUCTION}

The writing of scientific reports is crucial both for the effective transmission of knowledge and for its own acquisition [1]. Laboratory notebooks and reports constitute the first scientific writing experience for most undergraduates. The writing of Graduation thesis, Master thesis, first stage researcher report, etc., is more demanding, and often evidences a gap in the education. Transversal skills for written and oral communication are indispensable (not only to undergraduates and graduates, but also for lecturers and scientists). However, they are rarely provided by the university degrees. Effective presentation of results is an essential skill that may determine the employability of graduates in Science, Technology, Engineering and Mathematics (STEM).

Since 2016, we have been working on the development of materials to improve the communication skills of scientific results [2-4]. First, we carried out a compilation of the international standards that constitute the basis for the writing and oral presentation of the scientific material. The relevant documents published by official organizations, scientific societies, scientific publishers, associations of scientific publishers, etc., as well as numerous specialized monographs, were thoroughly reviewed. Then, highly recognized style guides and good teaching practices in the field were also identified.

As a result of these previous educational innovation projects, materials covering the various aspects of written and oral communication have been developed. Although the Physics degree has been central, these materials have been designed keeping in mind all STEM students and lecturers. Past students, though highly rating these materials, spotted the convenience of incorporating materials that combine ICT self-learning environments with traditional classroom teaching (blended learning) [5]. These new blended learning materials should facilitate the acquisition of the necessary oral and written communication skills, make more effective their presentation of results and, consequently, enhance their employability as graduates.

The development of effective mixed learning tools (blended learning) requires extensive experience in: (i) teaching experimental sciences, (ii) elaboration of curricular materials based on Information and Communication Technologies (ICT), (iii) design of multimedia environments, and (iv) project management and quality assessment. Given that significant advances in educational innovation often occur in interdisciplinary contexts [6], the team of this project is composed of lecturers with complementary skills and experience in several university degrees.

This project encourages and disseminates good academic practice in the communication of scientific results by combining traditional classroom teaching with online activities and resources. Its objective is the optimization of the teaching-learning process of the communication skills of scientific results by 
incorporating web questionnaires and other interactive content into the educational program [7]. Its development requires and encourages the active participation of the students, since the update of materials take into account the information received from users. That is, these self-learning materials are designed on the basis of the experience from previous projects and the suggestions and assessments made by the students. The project methodology includes educational data mining aimed at identifying the most effective materials and activities to achieve its objectives [8].

\section{METHODOLOGY}

The strategic lines of action of this project are the incorporation of ICT tools, and the use of active methodologies for learning. Online questionnaires are common ICT resources because they provide immediate results that are fairly objective and rigorous. Mixed learning tools (blended learning) have also been explored in educational psychology for quite some time. However, the development of these types of tools with the aim of improving scientific communication skills is original. The importance of this educational innovation project lies in the fact that there are not, to the best of our knowledge, similar initiatives to improve teaching quality by addressing the various aspects of communication of scientific results in such a rigorous and extensive way.

This e-innovation places the student at the center of the learning process, and incorporates pedagogical supports suited to their needs. In order to optimize the teaching and learning of communication skills of scientific results, an autonomous learning system with formative e-feedback has been developed. It complements the acquisition of this knowledge and of transversal skills through on-site classroom teaching. Self-learning activities are designed as an essential part of the educational plan of this educational innovation project. Students can thus better organize their own learning and teachers can track the acquisition of knowledge and skills, as well as identify the most effective activities and resources. That is, flexible use of ICTs is promoted to make learning more effective within a mixed on-site/on-line context. Students receive formative feedback from both the teacher and the self-learning platform. This methodology has great acceptance among students and makes their training work less arduous and more enjoyable.

The educational program incorporates online questionnaires and other interactive content developed, mainly but not exclusively, using the exe-learning tool. This is a free multiplatform software (that can be run on different OS) that allows easily designing and creating web content. The self-learning system is implemented through institutional web pages or through the institutional online platform (Moodle) thanks to the possibility of generating Shareable Content Object Reference Model (SCORM) questionnaires.

\section{ON-LINE QUESTIONNAIRES}

Based on the materials and results of the previous projects, the project team has developed a bank of multiple-choice questions with their corresponding e-feedbacks (Fig. 1). Using this question bank, online questionnaires have been designed, which can be implemented in institutional teaching web pages or in the Moodle institutional online platform. Most of the items serve to discuss different topics, such as the poor legibility, the choice of colors, the format of labels, etc. Throughout the project, still in execution, the data provided by the students using the questionnaires is analyzed. Then, the question bank and the questionnaires are both reviewed and updated. Especially important is the feedback given to the students in the case of a wrong answer because, in addition to the reflection on the error, it should encourage the search for the correct information in the study materials provided.

Official documents and their guides cannot be substituted by on-line questionnaires. However, they have shown to be effective tools to get to know those documents, to get acquainted with the rules of scientific communication, and to learn strategies for effective communication of scientific results. Some inconsistences can be found when consulting a large number of official documents on scientific writing. Therefore, a decision has to be made to rank their reliability. In the preparation of the databank and the questionnaires, the International System of Units has been given the highest rank, together with the accompanying guides prepared by the National Institute of Standards and Technology (NIST). ISO 80000 standards (agreed by the national standardization bureaus of the 162 ISO members) have been ranked second. The third rank has been given to the guides from the International Union of Pure and Applied Physics (IUPAP) and Pure and Applied Chemistry (IUPAC). Style guides from American Institute of Physics (AIP), American Chemical Society (ACS), Institute of Electrical and Electronics Engineers (IEEE), Institute of Physics (IOP), The Chicago Manual of Style, Oxford New Hart's rules, and recommendations from editorial offices of top scientific journals have also been considered. 
1) Unidades del Sistema Internacional (SI)

¿Qué magnitud física tiene el newton por metro como unidad coherente en el SI?

Energía

Tensión superficial o energía libre interfacial

Momento de fuerza

Ninguna de las anteriores

\section{ENVIAR RESPUESTAS}

Feedback example

๑) Momento de fuerza

La unidad SI de momento de fuerza es el newton metro, $\mathrm{N} \mathrm{m}$, y no el newton por metro, N/m.
4) Etiquetas de los ejes de una gráfica

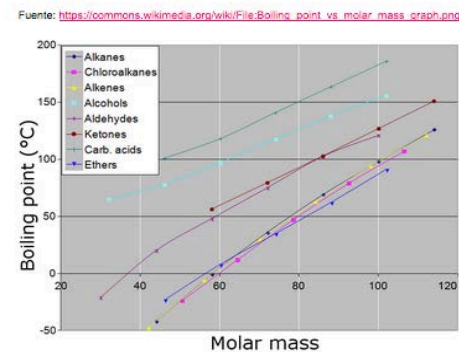

Molar mass

¿Deberia llevar unidades la etiqueta del eje de abscisas?

O No, pues la masa molar se mide de forma relativa al valor de referencia $1 \mathrm{~g} \mathrm{~mol}^{-1} \mathrm{y}$, por tanto, es adimensional.

O Si y debería ser "masa molarl $\left(\mathrm{g} \mathrm{mol}^{-1}\right)$ ".

O Si y el Sl admite usar como unidades de masa molar tanto $\mathrm{g} \mathrm{mol}^{-1}$ como Da.

O No, pues es suficiente con el adjetivo "molar" acompañando a la magnitud "masa".

ENVIAR RESPUESTAS

5) Marcas mayores y menores sobre los ejes

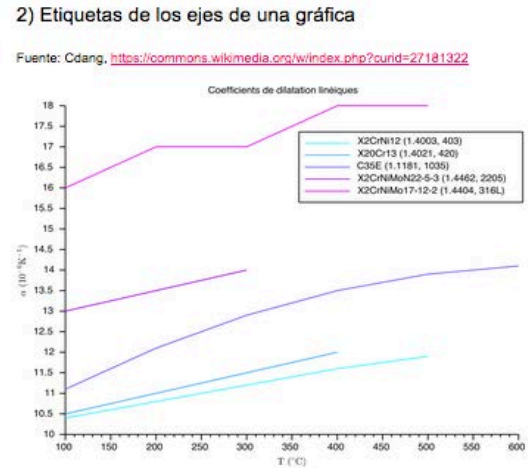

¿Cómo debería escribirse la etiqueta del eje de ordenadas?
$10^{-6} \mathrm{a}\left(\mathrm{K}^{-1}\right)$
$10^{6} a\left(\mathrm{~K}^{-1}\right)$
$10^{6} \alpha K^{-1}$
$10^{-6} \alpha / K^{-1}$

\section{ENVIAR RESPUESTAS}

\section{3) Símbolo log}

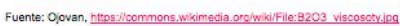

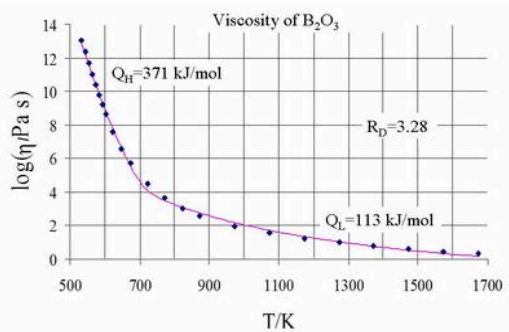

¿Qué representa el símbolo log en la etiqueta del eje de ordenadas?

O El símbolo log representa el logaritmo natural o neperiano.

O El símbolo log representa el logaritmo decimal.

Logaritmo en una base que no necesita ser especificada, pues este es el significado del símbolo log según la norma ISO 80000:2:2009, 2-12.4.

O Debe representar algún logaritmo que no corresponde al símbolo empleado.

ENVIAR RESPUESTAS

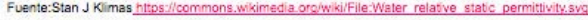

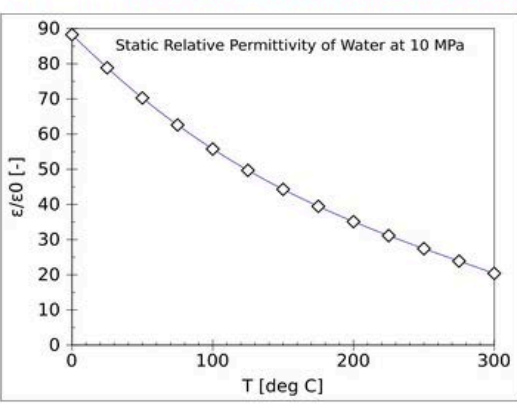

¿En qué dirección se deben dibujar las marcas sobre los ejes?

Las menores solo hacia adentro de la figura. Las mayores hacia dentro y también hacia fuera para así identificar mejor la correspondiente etiqueta de valor

Pueden estar hacia dentro, hacia afuera o en las dos direcciones, pero de igual modo las marcas mayores y menores.

O Tanto las mayores como las menores deber dibujarse hacia dentro.

Tanto las mayores como las menores deber dibujarse hacia fuera.

6) Etiquetas de los ejes de una gráfica

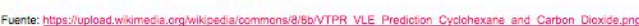

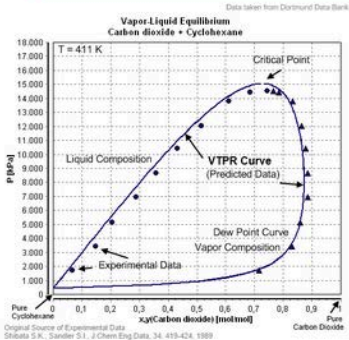

Dado que las fracciones molares $x$ (en fase líquida) e $y$ (en fase vapor) son adimensionales, ¿es correcto escribir mol/mol como unidad?

Siempre debe escribirse la unidad, pero si la magnitud es adimensional el Sl establce que el símbolo correspondiente es " 1 ".

No debe escribirse unidad en el caso de magnitudes adimensionales o definidas como cocientes de magnitudes de igual dimensión, como es el caso de las fracciones molares.

O El SI admite usar mol/mol como unidad de fracción molar e indica que este uso ayuda a entender mejor la manitud representada.

Debe escribirse $x, y$ (Carbon dioxide) [-], pues así se indica que es adimensional.

Figure 1. Examples of items of the online questionnaires. The first panel includes one example of feedback provided to the students after sending the answers. 


\section{CONCLUSIONS}

Teaching should not be limited to the transmission of knowledge to the students. It should also prepare them to be good communicators of scientific results. The ability to effectively transmit information in written documents and in multimedia presentations is a competence of enormous importance. The conventions in every scientific field must be known, and with the presentation style has to be adjusted to such conventions. Being able to fluently present your work, your achievements and their importance is essential in STEM. Possessing excellent communication skills is highly valued in job interviews.

The communication of scientific results is a complex activity that requires taking care of both the content and the form. An effective communication requires not only thorough preparation of content, but also good style. The presentation style must follow the established standards, and the flow of ideas must show a logical argument, because only in this way the audience keeps the interest. Different audiences need different communicative approaches, but they all deserve respect: careful preparation of the communication is mandatory.

Educational innovation projects on scientific communication cover an aspect of the teaching process that has been traditionally neglected or, at least, that has not received the necessary attention. Therefore, they can have a very significant impact on the graduate training.

\section{ACKNOWLEDGEMENTS}

This work has been supported by the University of Valencia through project SFPIE_PID19-1096780.

\section{REFERENCES}

[1] Kalman, C. S. Successful Science and Engineering Teaching. Theoretical and Learning Perspectives, 2nd ed., Springer: Cham, 2018.

[2] Manzanares, J. A.; Gilabert, M. A.; Mafé, S.; Garrido, J.; Cervera, J.; Martínez, B.; GarcíaMorales, V.; Ramírez, P.; Aguilella, M. I.; Alcaraz, A.; Aguilella, V. M. (2018). Recursos innovadores para mejorar las habilidades de presentación de resultados científicos. In M. D. Montagud (ed.) VII Jornades d'innvació docent en l'educació superior (pp. 86-95). Valencia: M $^{a}$ Dolores Montagud Mascarell.

[3] Ebel, H. F. et al. The Art of Scientific Writing, Wiley-VCH: Weinheim, 2004.

[4] Tufte, E. R. The Visual Display of Quantitative Information, Graphics Press: Cheshire, CT, 2001.

[5] Hubbard, R. The Really Useful eLearning Instruction Manual, Wiley: New York, 2013.

[6] Toffler, A. The Third Wave, Bantam Books: New York, 1980.

[7] Remesal, A. et al. "Uso de cuestionarios online con feedback automático para la e-innovación en el alumnado universitario", Comunicar 25, n. ${ }^{\circ} 51$ (2017) 51-60, doi:10.3916/C51-2017-05.

[8] Gibaja, E. et al. "Minería de datos educativos para la detección de recursos clave", Revista de Innovación y Buenas Prácticas Docentes, 3 (2017) 18-28, doi:10.21071/ripadoc.v3i0.9960. 